\title{
PENGEMBANGAN PUSAT PELATIHAN DAN SIMULASI KEJADIAN BENCANA ALAM UNTUK PENDIDIKAN KEBENCANAAN NASIONAL
}

\author{
Oleh: Ahmad Yani*)
}

\begin{abstract}
Abstrak
Pendidikan Kebencanaan Nasional merupakan pendidikan yang sangat dibutuhkan di negara yang selalu dihadang oleh bencana. Namun untuk dilembagakan masih sangat sulit dilakukan. Tulisan ini dapat dijadikan bahan bacaan awal untuk memulai usaha membangun Pendidikan Kebencanaan pada umumnya dan pendirian Pusat Pelatihan dan Simulasi Kejadian Bencana Alam pada khususnya. Sambil menanti terwujudnya gagasan ini, sebaiknya pendidikan kebencanaan sudah dimulai oleh semua pihak terutama oleh para guru IPS dan Geografi di sekolah. Sekolah yang telah mencoba melakukan simulasi evaluasi gempa bumi, banjir, dan kebakaran patut dihargai, apalagi jika sudah dijadwalkan secara rutin di sekolah.
\end{abstract}

Kata Kunci: bencana, pendidikan, simulasi

*) Drs. Ahmad Yani, M.Si., adalah dosen Jurusan Pendidikan Geografi FPIPS-UPI.

\section{Pendahuluan}

Indonesia adalah negara rawan bencana geologi atau bencana alam seperti gempa bumi, tanah longsor, dan gunungapi meletus. Untuk mengurangi korban jiwa dan harta benda, banyak pihak yang mengusulkan agar masyarakat diberi pemahaman yang benar tentang bencana alam sebagai upaya mitigasi bencana. Secara ilmiah, mitigasi (mitigate) berarti tindakan-tindakan untuk mengurangi bahaya supaya kerugian dapat diperkecil. Mitigasi meliputi tindakan perlindungan yang dapat diawali dari persiapan sebelum bencana itu berlangsung, menilai bahaya bencana, penanggulangan bencana, berupa penyelamatan, rehabilitasi dan relokasi. Menurut Keputusan Menteri Dalam Negeri RI No. 131 Tahun 2003, mitigasi adalah upaya yang dilakukan untuk mengurangi dan memperkecil akibatakibat yang ditimbulkan oleh bencana, yang meliputi kesiapsiagaan serta penyiapan kesiapan fisik, kewaspadaan dan kemampuan. Kegiatan kesiapsiagaan antara lain berupa pelatihan atau pembelajaran untuk menyiapkan diri pada saat bencana terjadi.

Dari sekian banyak kegiatan mitigasi, satu yang paling strategis adalah pembelajaran atau pendidikan kepada masyarakat. Pendidikan merupakan wahana yang efektif untuk membangun perilaku masyarakat dalam menghadapi bencana. Dalam referensi Biro Mitigasi Sekretariat Bakornas PBP (2005), mitigasi bencana yang berbasis pada pendidikan masyarakat disebut paradigma pengurangan resiko. 
Mitigasi bencana awalnya memang bersifat konvensional yang menganggap bencana sebagai suatu peristiwa atau kejadian yang tidak dapat dielakan dan tidak dapat dikurangi resikonya. Prinsip utamanya agar para korban segera mendapat pertolongan, sehingga fokusnya memberi bantuan atas kedaruratan (emergency). Pandangan kedua berkembang menjadi paradigma antisipasi; tujuannya lebih diarahkan kepada identifikasi daerah-daerah rawan bencana, mengenali pola-pola yang dapat menimbulkan bencana, dan penataan ruang. Pandangan ketiga adalah paradigma pembangunan yaitu bersifat mengintegrasikan upaya penanganan bencana dengan program pembangunan, misalnya melalui perkuatan ekonomi, penerapan teknologi, pengentasan kemiskinan dan sebagainya. Pandangan keempat adalah paradigma pengurangan resiko. Dalam paradigma terakhir ini penanganan bencana bertujuan untuk meningkatkan kemampuan masyarakat untuk mengelola dan menekan resiko terjadinya bencana. Pendekatan ini memandang masyarakat sebagai subyek dan bukan obyek dari penanganan bencana dalam proses pembangunan.

Pada paradigma pengurangan resiko, mitigasi dimaknai sebagai kewajiban berbagai pihak, baik para ahli, pemerintah, maupun masyarakat secara luas. Para ahli barangkali memiliki tugas untuk menjelaskan peristiwa terjadinya gempa, gunung api, longsor, atau banjir. Dengan pengetahuannya, mereka memetakan tempat-tempat rawan bencana. Saat ini sudah dikembangkan suatu sistem peringatan dini (Early Warning System). Uji cobanya pernah dilakukan di daerah Yogyakarta dan sekitarnya dengan menggunakan layanan Value Added Short Message Service (VASMS). Layanan SMS merupakan teknologi yang dapat diakses secara mudah dan dapat diterima oleh masyarakat luas dalam waktu yang singkat. Dengan tingkat kepemilikan handphone yang cukup tinggi, pemanfaatan channel layanan seluler akan lebih efektif. Layanan Jogja Early Warning System ini adalah gagasan dari PT. Inspira Inovasi Indonesia sebagai anak perusahaan PT. Gamatechno Indonesia dengan Badan Meteorologi dan Geofisika (BMG) Yogyakarta dan didukung oleh Badan Informasi Daerah (BID) Propinsi Yogyakarta, yang bertujuan untuk memberikan pelayanan informasi bencana kepada masyarakat Yogyakarta dan sekitarnya.

Kewajiban pemerintah adalah mengkaji dan menguatkan koordinasi dan komunikasi untuk kelancaran bantuan dan pencegahan dampak sampingan yang menimbulkan bertambahnya korban. Peran serta pemerintah sangat penting, karena untuk hal yang dianggap mudah seperti distribusi bantuan bagi korban bencana ternyata tidak sesederhana yang kita pikirkan. Banyak pihak yang kesulitan untuk menyampaikan bantuan dengan tepat. Di sejumlah media massa selalu ada laporan tentang keluhan masyarakat yang belum mendapat bantuan tetapi di tempat lain justru sangat menumpuk. Kasus yang menyakitkan, justru ada oknum "relawan" yang mengambil bantuan untuk kepentingan pribadinya. Sebut saja kasus yang mencuat ke permukaan dengan isu pengambilan barang (maling) sumbangan bantuan Aceh oleh sekelompok relawan pada tahun 2005.

Adapun tanggung jawab masyarakat adalah menguatkan ketangguhan dirinya sendiri dalam mengatasi bencana. Untuk melahirkan masyarakat yang 
tangguh, perlu ada upaya pembelajaran tentang bencana alam agar mereka dapat berusaha menghindari resiko yang lebih banyak dan memakluminya dengan kesabaran. Forum atau sarana yang telah banyak dimanfaatkan untuk memperkuat masyarakat antara lain pengajian, rapat-rapat di kelurahan, penyebaran leaflet, poster, dan lain-lain.

Semua yang telah dijelaskan di atas sudah dan sedang dilaksanakan. Namun apakah sudah dapat menjamin adanya berkelanjutan. Kenyataannya, ketika gempa terjadi atau banjir bandang menyapu permukiman, kita cenderung kembali kepada tahap awal perkembangan mitigasi yaitu yang bersifat konvensional. Semua orang panik dan pasrah kepada nasib. Di koran, radio dan televisi berkumandang lagi ajakan untuk membantu meringankan penderitaan. Bukti bahwa kita memiliki pola mitigasi konvensional, misalnya pada saat wartawan mewawancari masyarakat korban bencana, ia akan bertanya: "apakah sudah ada bantuan dari pemerintah?". Dijawab oleh masyarakat ".....belum!, kami berharap agar pemerintah segera membantu kami!". Jika telat diberi bantuan, mereka berdemo dan mendesak agar Bupati atau Guberbur turun dari singgasananya!. Pertanyaan wartawan yang normatif (cenderung tidak kreatif) tersebut adalah bukti yang perlu kita evaluasi. Pemerintah dianggap dewa penyelamat yang banyak uang, dan masyarakat kurang berperan serta dalam mengatasi masalah. Pertanyaan wartawan itu adalah bukti ketiadaan sistem yang baik dalam mengatasi masalah pasca bencana.

\section{Kesiagaan Melalui Pengintegrasian Kurikulum}

Pengintegrasian materi kebencanaan dalam kurikulum di sekolah banyak digagas oleh banyak pihak. Prakoso Bhairawa Putera S, Peneliti Muda Kebijakan dan Perkembangan Iptek - LIPI pernah menulis di $P R$ online tentang penyampaian materi kesiagaan bencana yang diintegrasikan dengan mata pelajaran. Sebelum ada kebijakan tentang pendidikan kebencanaan, ia menyarankan agar ada pelatihan untuk siswa, guru, ataupun karyawan. Materi pelatihan diarahkan untuk peningkatan ketrampilan menghadapi bencana dan mengkaji perencanaan menghadapi bencana.

Selanjutnya Prakoso menyatakan bahwa untuk masyarakat umum, sosialisasi kebencanaan dapat berupa penyuluhan interaktif yang dilakukan secara rutin dengan melibatkan unsur lembaga swadaya masyarakat (LSM), pemerintah, dinas kesehatan, pemadam kebakaran, palang merah, angkatan bersenjata, hingga pekerja kantor dan para profesional.

Menurut Prakoso, Jepang sudah melaksanakan metode pendidikan kesiapsiagaan terhadap bencana sejak 1971. Hampir di setiap kota besar dan prefectures di Jepang terdapat pusat pelatihan pencegahan bencana. Pusat pelatihan ini menyediakan latihan dan simulasi secara gratis kepada setiap warga negara maupun pengunjung. Simulasi yang disediakan meliputi simulasi gempa bumi (jishin), simulasi badai (taihu), pemadaman api menggunakan fire extinguisher, penyelamatan ketika kebakaran, permainan mengendarai helikopter untuk mengevakuasi korban bencana, dan lainnya. Pelajar setingkat shogakko (sekolah dasar) berkewajiban untuk mendatangi, mengenal, dan mengikuti simulasi 
pencegahan bencana di pusat pencegahan bencana terdekat. Semua diintegrasikan dengan kurikulum belajar.

Jepang menurut penulis adalah negara yang serius menciptakan suasana kesiagaan dengan adanya pusat-pusat pelatihan dan simulasi. Dengan adanya pusat pelatihan mitigasi bencana diharapkan akan terbangun pemahaman tentang mitigasi bencana yang terintroduksi sejak dini sehingga kelak akan memiliki perilaku kesiagaan mitigasi bencana yang melekat.

Bagaimana dengan Indonesia?. Pelatihan menghadapi bencana umumnya tanpa koordinasi dan sporadis. Di sekolah-sekolah hanya dilakukan seadanya dan oleh sekolah-sekolah yang peduli saja. Di lingkungan pesantren juga pernah dirintis. Sebut saja di Pesantren Darussalam Watucongol Magelang pernah menyelenggarakan Pelatihan Manajemen Resiko Bencana Bagi Guru/Ustadz dan santri Senior. Kegiatan pelatihan kerjasama antara Community Based Disaster Risk Management Nahdlatul Ulama (CBDRMNU) Kabupaten Magelang bersama Project Manager Unit (PMU) CBDRMNU Jakarta. Kegiatan ini diikuti oleh 25 orang guru (ustadz) dan murid senior dari 5 kleompok Kecamatan yang telah dibentuk oleh Santri Siaga Bencana Kabupaten Magelang ( $N U$ online).

Walaupun kegiatan pendidikan bersifat sporadis dan tidak berkelanjutan tetapi sebagai usaha masyarakat patut dihargai. Sekurang-kurangnya dapat memberi wawasan singkat tentang bencana. Namun jika ditakar dengan besarnya masalah yang dihadapi, usaha yang sporadis dan angin-anginan tersebut tentu saja tidak memadai. Perlu direncanakan dengan manajemen yang lebih baik. Di dalamnya perlu ada lembaga pendidikan dan pelatihan yang dilengkapi dengan berbagai alat simulasi untuk mendukung latihan.

\section{Pusat Pelatihan Dan Simulasi Kejadian Bencana}

Bencana berdasarkan sumber penyebabnya dapat dibedakan atas lima yaitu (a) bencana geologis berupa letusan gunung api, gempa, longsor dan gerakan tanah, (b) Bencana klimatologis berupa kekeringan, badai, dan banjir; (c) Bencana meteorit, jatuhnya benda langit ke permukaan bumi; (d) bencana lingkungan berupa kebakaran hutan polusi, dan kegagalan teknologi lainnya, (e) bencana akibat ulah manusia berupa rusaknya budaya masyarakat yang unggul oleh berbagai pengaruh seperti konflik antar etnis, KKN, Korupsi, penyakit, dan sebagainya. Karakteristik bencana alam yang banyak terjadi di Indonesia menurut BAKORNAS (2005) adalah: Banjir, Tanah longsor, Kekeringan, Kebakaran Hutan dan lahan, Angin Badai, Gempa Bumi, Tsunami, Letusan Gunungapi, Kegagalan Teknologi, dan Wabah penyakit. Namun dari semua bencana yang disebutkan ada bencana yang bersifat mendadak antara lain gempa bumi, tsunami, tanah longsor, banjir bandang, dan angin ribut.

Untuk bencana alam yang tidak mendadak barangkali mudah untuk dihindari, walaupun tetap harus dipersiapkan mental para korban karena dampaknya bisa lebih besar dan meluas. Bencana kekeringan, misalnya, walaupun memiliki waktu jeda yang panjang tetapi jika korban tidak mendapat solusi yang cepat akan merembet pada krisis lainnya yang lebih berbahaya. 
Bencana alam yang bersifat mendadak dapat juga dibagi lagi menjadi dua yaitu yang dapat terantisipasi dan tidak dapat terantisipasi. Yang dapat terantisipasi antara lain tanah longsor dan banjir bandang sedangkan yang tidak terantisipasi adalah gempa bumi, tsunami, angin ribut. Jika dibandingkan lagi antara gempa bumi, tsunami, dan angin ribut maka gempa bumi adalah bencana yang tidak memiliki jeda sama sekali.

Pusat pelatihan dan simulasi kejadian bencana alam yang akan diusulkan dalam tulisan ini adalah untuk pendidikan kebencanaan yang bersifat mendadak yaitu gempa bumi, tsunami, tanah longsor, banjir bandang, dan angin ribut. Artinya diversifikasi pusat pendidikan dan pelatihan diperuntukan untuk mitigasi lima bencana alam di atas. Sebagaimana pusat pendidikan dan pelatihan (Pusdikat) yang lain, ada sejumlah persyaratan untuk mendirikan pusdiklat kebencanaan antara lain kurikulum, sarana dan prasarana, peserta, dan instruktur. Berikut ini adalah gagasan awal untuk membangun pusdiklat kebencanaan yang bermanfaat bagi mereka yang akan merintis dan mewujudkan gagasan ini.

\section{a. Kurikulum Kebencanaan}

Kurikulum kebencanaan sekurang-kurangnya memiliki ruang lingkup empat aspek yaitu:

1) Pendidikan pencegahan yaitu upaya preventif agar kerusakan dan korban dapat dikurangi jika terjadi bencana.

2) Pendidikan tanggap darurat yaitu upaya mencarian, penyelamatan, dan evakuasi serta pemberian bantuan darurat (sandang, pangan, obat-obatan, perlindungan dan lain-lain).

3) Pendidikan rehabilitasi yaitu perbaikan fisik dan non fosik serta pemberdayaan dan mengambaian harkat hidup korban bencana

4) Pendidikan rekonstruksi yaitu pembangunan kembali prasarana/sarana serta fasilitas umum yang rusak agar kehidupan normal kembali.

Dari empat aspek di atas, akan mudah diurai menjadi sejumlah kompetensi dasar yang harus dicapai oleh peserta diklat. Untuk pencapaian kompetensi biasanya akan dipertimbangkan dua hal yaitu waktu dan peserta diklat. Waktu diklat mungkin dapat dikelompok pada empat paket yaitu:

1) Paket Wisata

2) Paket Sosialisasi

3) Paket Dasar

4) Paket Manajer

Paket wisata merupakan paket short time yaitu pelatihan dengan waktu 1 atau 2 jam saja. Tujuannya hanya mengenal secara umum tentang berbagai bencana dan cara cepat menyelamatkan diri. Paket ini cocok bagi pelajar dan masyarakat umum dari TK, SD, SMA, PT, dan masyarakat awam. Kegiatan pelatihan adalah menyaksikan pameran, pemutaran film, simulasi di tempat khusus baik di dalam ruangan maupun halaman yang sudah dirancang untuk melakukan latihan dalam menghadapi bencana. Untuk gempa bumi, perlu diracang bangunan mekanik simulasi gempa bumi. Walaupun pelatihan bersifat serius tetapi di dalamnya sarat 
dengan suasana wisata. Instruktur diangkat dan ditugaskan dari pusat diklat yang telah terlatih.

Paket Sosialisasi merupakan pelatihan bagi relawan amatir dengan fokus pada pendidikan pencegahan, tanggap darurat, rehabilitasi dan rekonstruksi. Walaupun ruang lingkupnya sangat luas tetapi pembekalan hanya diarahkan untuk menjadi relawan setempat. Artinya peserta yang mengikuti diklat adalah para pemuda yang berasal dari daerah-daerah rawan bencana. Mereka diambil dari para anggota karang taruna dengan pendidikan setingkat SMP dan SMA. Peserta diutus dan dibiayai oleh pemerintah daerah. Kompetensi yang diharapkan adalah menjadi agen sosialisasi dan pemandu teknis bagi masyarakat sekitarnya. Waktu pelatihan antara 7 - 10 hari. Materi teori yang disarankan antara lain tentang kebencanaan, karakteristik korban, dan teori SAR. Materi praktek antara lain P3K, evakuasi, dan rehabilitasi sementara.

Paket Dasar merupakan pendidikan dan latihan bagi para relawan dari Lembaga Swadaya Masyarakat, Anggota SAR, pejabat pemerintah tingkat lokal, dan para teknisi sarana umum seperti para pedam kebakaran, instalasi listrik, gas, dan air, para perancang transportasi darat, para psikolog, dan lain-lain. Waktu pelatihan antara 20 - 30 hari dengan peserta yang relatif homogen. Artinya pelatihan tidak dapat dilakukan bagi semua latar belakang profesi. Pelatihan dibantu oleh pemerintah pusat dengan tujuan agar para teknisi sarana umum tersebut dapat melakukan rehabilitasi dan rekonstruski sarana umum dengan cepat. Para pelatih pada paket dasar adalah para ahli bencana, praktisi sarana umum, psikolog, kepolisan, dan para instruktur dari komponen SARNAS dan TNI.

Paket manajer merupakan pelatihan bagi para pimpinan dan pengambil keputusan. Peserta terdiri dari para camat, bupati, gubernur, para anggota dewan, pimpinan perusahaan tertentu, dan lain-lain. Waktu pelatihan fleksibel sesuai kesepakatan antara lembaga diklat dengan para peserta dan atau perintah dari atasan. Materi yang disampaikan berupa mitigasi tingkat manajer. Dampak yang diharapkan dari pelatihan ini adalah agar para pimpinan memiliki wawasan kebencanaan. Aturan hukum yang dibuat oleh pemerintah daerah dan anggota dewan mempertimbangkan aspek bencana alam.

\section{b. Sarana dan prasarana}

Untuk membangun pusat pelatihan diklat kebencanaan tergantung pada kurikulum yang akan dikembangkan. Di bawah ini digagas sarana dan prasarana lengkap untuk semua paket diklat:

1) Ruang pelatihan yang memuat 40 orang peserta

2) Ruang simulasi gempa bumi

3) Halaman untuk simulasi evakuasi dan pertolongan pertama

4) Ruang pameran dan alat peraga baik 2 maupun 3 dimensi

5) Ruang pemutaran film

6) Perpustakaan

7) Ruang Pusat studi kebencanaan

8) Laboratorium forensik kebencanaan 
9) Gudang pemeliharaan peralatan praktek

10) Ruang instruktur dan administrasi

11) Penginapan peserta

12) Sarana peribadatan

13) Dan sarana lain yang diperoleh atas kerjasama yang baik dengan instansi terkait misalnya markas besar SARNAS, BMG, PVMBG (Pusat Vulkanologi, dan Mitigasi Bencana Geologi), kepolisian, 3 unsur TNI (Darat, Laut, dan Udara), dan kerjasama internasional.

\section{c. Peserta}

Sebagaimana telah disinggung pada bagian kurikulum, peserta adalah dari semua unsur dari kalangan pelajar dari TK sampai PT, unsur kepemudaan, masyarakat awam, para relawan, para teknisi sarana umum, kepala daerah dan anggota dewan. Pelayanan paket yang harus banyak dilakukan adalah paket wisata dan paket sosialisasi karena keduanya adalah sasaran utama pendidikan masyarakat. Sedangkan Paket Pelatihan Dasar da Manajer mungkin jarang dilakukan tetapi harus disediakan paketnya agar lebih terintegrasi dalam membangun masyarakat siap menghadapi bencana.

\section{d. Produk Pusat Diklat Kebencanaan}

Selain sebagai pusat pendidikan dan latihan, Pusdiklat juga memiliki peranan penting untuk mengembangkan berbagai teknologi dan produk informasi lainnya yang bermanfaat bagi masyarakat misalnya;

1) Peta rawan dan komunitas rentan bencana dan mendisiminasikannya kepada seluruh masyarakat.

2) Perencanaan kedaruratan (contingency planning)

3) Perencanaan dan temuan teknologi early warning system yang dipahami oleh seluruh lapisan masyarakat

4) Mengevaluasi seluruh kebijakan yang berpotensi meningkatkan kerentanan bencana yang bersifat kasuistik

\section{Pendidikan Kebencanaan Nasional}

Pendidikan Kebencanaan Nasional merupakan gagasan besar yang banyak diinginkan oleh banyak pihak tetapi sulit untuk dilembagakan. Para ahli pendidikan, para pengelola, dan para praktisi pendidikan di lapangan semuanya menunggu. Walaupun harus diakui, tidak tahu siapa yang sedang ditunggu. Sebagian dari mereka sudah mencoba angkat bicara tetapi frekwensinya naik turun. Di saat musibah datang, barulah banyak orang yang berbucara, sebaliknya jika tidak ada kejadian bencana suaranya nyaris tidak terdengar. Tulian ini juga bagian dari bisik-bisik yang mungkin didengar mungkin tidak. Sebagai penulis, saya tidak pernah putus asa. Sekurang-kurangnya dapat dibaca oleh mahasiswa jurusan pendidikan geografi dan para guru di sekolah.

Untuk menggagas pusat pendidikan dan pelatihan rasanya cukup jelas kegiatannya. Sebagai tambahan, Pusdilat kebencanaan idealnya dibangun di setiap 
kota provinsi dan atau kabupaten. Kedudukannya hampir sama dengan kepentingan kita terhadap perpustakaan daerah dan musium daerah. Embrio pendirian Pusdiklat dapat dirintis oleh perguruan tinggi setempat yang bekerjasama dengan Satuan Koordinasi Pelaksana Penanggulangan Bencana dan Penanggulangan Pengungsi setempat. Jika perlu, kewenangan pendirian diklat bisa juga dilakukan oleh Satkorlak tingkat kabupaten/kota.

Sambil menunggu reaksi dan tanggapan dari masyarakat dan pihak lainnya, Pendidikan Bencana Nasional bisa kita mulai dari sekolah. Walaupun tidak ada ruang kurikulum di sekolah bagi Pendidikan Kebencanaan (nasibnya sama dengan Pendidikan Lingkungan Hidup), namun pendidikan kebencanaan perlu terus dihidupkan. Bagi guru IPS (di SD dan SMP) dan Geografi di SMA Pendidikan Kebencanaan merupakan kewajiban kita untuk terus disosialisasikan. Caranya dapat disinggung pada setiap penyampaian kompetensi mata pelajaran. Sesekali coba melakukan simulasi bencana gempa bumi seperti yang pernah dilakukan disejumlah sekolah:

1) SD Alzhar Jakarta pada akhir tahun 2009,

2) TK dan SD Karangturi Semarang, yang bekerja sama dengan Palang Merah Indonesia (PMI) Kota Semarang itu menceritakan terjadinya bencana gempa bumi yang menyebabkan bangunan sekolah runtuh dan terbakar.

3) SD Panunggangan 1 dan 4, Panunggangan Barat, Cibodas, Kota Tangerang menggelar simulasi gempa dan banjir, pada Kamis 18/2/2010.

4) Sekolah Dasar Negeri 4 Lampegan di Garut, Jawa Barat sekitar Oktober 2009

5) Taman kanak-kanak (TK) dan sekolah dasar (SD) Priangan Bandung, Jawa Barat, menggelar simulasi gempa bumi dan kebakaran pada sekitar Oktober 2009.

6) Dan mungkin di tempat lainnya.

Walaupun hanya bersifat parsial tetapi itulah kepedulian guru dalam memberi pengalaman simulasi gempa bumi kepada masyarakat. Jika usaha semacam itu tidak bisa dilakukan, guru IPS dan geografi sebaiknya dapat melakukan hal-hal sebagai berikut:

1) Lakukan mitigasi bencana sebelum memulai pembelajaran. Setelah berdoa, sebaiknya guru mempersilakan siswa untuk mengatur dan merencanakan evakuasi jika gempa tiba-tiba terjadi (jalur pelarian sudah dibayangkan oleh seluruh siswa). Ini dilakukan setiap hari sebagai bentuk kewaspadaan bersama.

2) pembiasaan kepada anak didik untuk melakukan mitigasi bagi dirinya sendiri (cara meloloskan diri) jika berada di sebuah bangunan (di hotel, di sekolah, di tempat ibadah, di tempat pertemuan, dan lain-lain). Pembiasaan yang harus dilakukan misalnya sekilas memastikan jumlah meja yang kuat dalam ruangan, arah pintu keluar, pilar/tiang bangunan pokok, lokasi alat pemadam kebakaran, toliet, dan bentuk bangunan secara keseluruhan. Tidak harus diperiksa secara teliti, tetapi cukup dilirik oleh mata secara sekilas. Jika terjadi gempa maka dalam benaknya sudah tergambar tempat yang akan dituju untuk berlindung.

3) Kewaspadaan jika melihat potensi bahaya. Hal ini biasa dilakukan oleh para pencinta alam yang melakukan perjalanan di tengah hutan. Jika melihat 
percikapn api atau puntung rokok, mereka segera akan mematikannya. Kita juga seharusnya dapat melakukannya, misalnya waspada terhadap potensi tanah longsor, banjir, atau kebakaran.

\section{Penutup}

Gagasan besar ini bukanlah sesuatu yang mustahil untuk dilaksanakan. Lembaga pendidikan yang memeroduksi guru seperti Universtas Pendidikan Indonesia dan universitas-universitas lain bekas IKIP sebaiknya menjadi pelopor dalam mewujudkan Pendidikan Kebencanaan Nasional. Bagi para ilmuwan dan praktisi pendidikan, Pendidikan Kebencanaan Nasional sebaiknya sudah mulai dirintis untuk dijadikan sebagai ilmu tersendiri sebagamana Pendidikan Lingkungan Hidup.

\section{Daftar Pustaka}

Coburn, AW., RSJ. Spence \& A. Pomonis. 1994. Mitigasi Bencana. Architectural Reseach Limited, The Oast House, Malting Lane, United Kingdom, Available: http://www.undmtp.org/Indonesia/Disaster_mitigation/Mitigasi

Direktorat Vulkanologi dan Mitigasi Bencana, Departemen Energi dan Sumberdaya Mineral, Gempa Bumi dan Tsunami. Bandung.

Gustavo Wilches, 1995, Bencana dan Lingkungan, Program Pelatihan manajemen Bencana, UNDP. http://www.undmtp.org/ Indonesian/ Disaster_mitigation/Mitigasi

Reed, Shelia, 1995, Pengantar Tentang Bahaya, Program Pelatihan Manajemen Bencana.UNDP.

Sarwedi Oemardi. "Pendidikan dan Mitigasi Bencana Alam: Pelajaran Berharga dari Aceh", Homepage Pendidikan Network, 2 Januari 2005.

UNDP, 1992, Tinjauan Umum Manajemen Bencana, Program Pelatihan Manajemen Bencana. 